\section{Maturation fruits and drying on quality of crambe seeds}

\author{
Hugo Tiago Ribeiro Amaro ${ }^{1^{*}}$ D, Eduardo Fontes Araujo ${ }^{2}$ D, Roberto Fontes \\ Araujo $^{3}$ iD, Luiz Antônio dos Santos Dias ${ }^{2}$ (D) Fabrício Welington Souza Silva² ${ }^{2}$, \\ Andréia Márcia Santos de Souza David ${ }^{1}$ iD
}

\begin{abstract}
This study aimed to evaluate the effect of maturation fruit and drying temperatures stages on oil content and the physiological performance of crambe seeds. Randomized blocks were the experimental design, with four replications. Harvests occurred when the plants reached 20,40,60, 80 and 100\% brown color fruits. After harvest, seeds were dried at different temperatures (natural and artificial air at 30, 45 and $60^{\circ} \mathrm{C}$ ). The seeds were evaluated for the weight of a thousand seeds, productivity, oil content, germination and vigor (count of the first germination and seedling emergence). Crambe seeds, FMS Brilhante cultivar, reach the maximum oil content with harvests made from $70 \%$ of total brown color fruits. Drying temperatures do not affect the oil content of the seeds. Harvesting crambe seed aiming at the highest physiological quality should occur when the plants have between 75 and $85 \%$ brown fruits. Artificial drying at 30 and $45^{\circ} \mathrm{C}$ can be recommended for crambe seeds, favoring the production of quality seeds.
\end{abstract}

Index terms: Crambe abyssinica Hochst, biodiesel, germination, vigor.

\section{Maturação de frutos e secagem na qualidade de sementes de crambe}

RESUMO: Este estudo teve como objetivo avaliar o efeito dos estádios de maturação dos frutos e das temperaturas de secagem sobre o teor de óleo e o potencial fisiológico das sementes de crambe. $O$ delineamento experimental foi o de blocos casualizados, com quatro repetições. A colheita ocorreu quando as plantas atingiram 20, 40, 60, 80 e $100 \%$ de frutos de cor marrom. Após a colheita, as sementes foram secas em diferentes temperaturas (ar natural e artificial a 30,45 e $60^{\circ} \mathrm{C}$ ). As sementes foram avaliadas quanto ao peso de mil sementes, produtividade, teor de óleo, germinação e vigor (primeira contagem de germinação e emergência de plântulas). As sementes de crambe, cultivar FMS Brilhante, atingiram o teor máximo de óleo com colheitas feitas a partir de $70 \%$ do total de frutos de cor marrom. As temperaturas de secagem não afetaram o teor de óleo das sementes. A colheita de sementes de crambe visando a mais alta qualidade fisiológica deve ocorrer quando as plantas tiverem entre 75 e $85 \%$ de frutos marrons. A secagem artificial a 30 e $45{ }^{\circ} \mathrm{C}$ pode ser recomendada para sementes de crambe, favorecendo a produção de sementes de qualidade.

Termos para indexação: Crambe abyssinica Hochst, biodiesel, germinação, vigor.
Journal of Seed Science, v.43, e202143003, 2021

http://dx.doi.org/10.1590/ 2317-1545v43235272

${ }^{1}$ Departamento de Ciências Agrárias, Universidade Estadual de Montes Claros (Unimontes) - Caixa Postal 91, 39448-524, Janaúba, MG, Brasil.

${ }^{2}$ Departamento de Agronomia, Universidade Federal de Viçosa (UFV) 36570-900, Viçosa, MG, Brasil.

${ }^{3}$ Empresa de Pesquisa Agropecuária de Minas Gerais (EPAMIG) - Caixa Postal 216, 36571-000, Viçosa, MG, Brasil. 


\section{INTRODUCTION}

With the production and use stimulus of biodiesel, crambe is one of the best options for supplying raw material for the sector due to its cultivation adaptability in tropical and subtropical climate and the high oil content in the seeds. Colodetti et al. (2012) cited the importance of crambe in the production of biodiesel, with most of the oils used for this purpose coming from annual crops, mainly crops with spring and summer cycles, lacking options at other seasons that allow the continuity of production of biodiesel and use in industry. However, there is a lack of information on crop management, especially regarding the production system of seed quality.

From the physiological maturity to the time of its use in the sowing, the seeds are subject to quality loss due to the biochemical and physiological changes (Garcia et al., 2004), often due to stresses during these steps. Thus, it to know the process of development and maturation of the seeds is important to establish the best harvest time, when the seeds show the maximum germination and vigor.

The initial studies carried out with the objective of characterizing the seed maturation process of cultivated plants were mainly aimed at determining differences in the phenology of species and cultivars and the evaluation of parameters to indicate the appropriate time for harvesting (Marcos-Filho, 2015). It is noteworthy that, under field conditions, the evolution of each characteristic of maturation is not easy to be monitored and the setting of a date or time for the occurrence of physiological maturity due to events such as sowing, flowering and fruiting may present differences for the same species and cultivar due to local climatic conditions, plant nutritional status, among other factors. Therefore, it is interesting to know other parameters that allow the detection of physiological maturity, correlating it with morphological characteristics of the plant, fruits and /or seeds.

To establish the ideal harvest point for a crop, it is important to know the process of formation and maturation of its fruits and seeds (Lucena et al., 2013). The crambe has an indeterminate flowering habit (Oliveira et al., 2014). For these plants, flowering and, consequently, seed production occurs for an extended period, which shows the maturation and harvest effects on the quality of the seeds. Therefore, seeds harvested in different racemes or positions in the raceme are affected by the environmental conditions in force during their formation and may present different germination and vigor (Lucena et al., 2006). Thus, early harvest may compromise quality mainly due to the occurrence of immature seeds (Melo and Ribeiro, 1990). On the other hand, delayed harvesting can compromise seed quality as seeds are exposed to the weather for a longer period, resulting in seed deterioration even in the field of production.

Studying harvest times and physiological quality of crambe seeds, Oliveira et al. (2014) concluded that the best time to harvest crambe seeds, cultivar FMS Brilhante, with higher physiological quality (maximum germination and vigor) occurs within 14 to 26 days after flowering. Although there is growing interest in the crop, research on seed maturation of this species is still scarce, especially when the objective is to identify morphological characteristics of the plant, fruits and / or seeds, correlating them with seed maturation.

Seeds, freshly harvested from the field, may often have an inadequate water content to be safely stored, thus, they need to be dried (Carvalho and Nakagawa, 2012). High water content can affect seed quality not only during harvesting operations, but also during processing and storage. Smaniotto et al. (2014) evaluating the physiological quality of soybean seeds stored under different conditions, observed that the initial water content influences the quality of soybean seeds during storage.

In the postharvest phase of plant products, drying is the most widely used process to assure its quality and stability since decreasing the amount of water in the material reduces the biological activity and the chemical and physical changes that occur during storage (Ullmann et al., 2010). However, the optimal drying conditions for the crambe seed plots are not yet well established, which could make unfeasible the production of seeds with the quality required by the market. In order to determine the drying behavior of the crambe seeds, it is important to note that the drying procedures are recent and it cover the aspects related to drying kinetics (Faria et al., 2012; Costa et al., 2013) and drying (Costa et al., 2012; Martins et al., 2012). Thus, there is a need for research aiming the selection of types and 
methods of drying more appropriate for the production of seeds with high quality standard.

Given the above, this study aimed to evaluate the effect of maturation and drying temperatures stages on oil content and the physiological and physical features of crambe seeds.

\section{MATERIAL AND METHODS}

The seeds were produced at the Experimental Field of the Department of Plant Science of the Universidade Federal de Viçosa, Minas Gerais, whose geographical coordinates are $20^{\circ} 45^{\prime} 14^{\prime \prime}$ south latitude and $42^{\circ} 52^{\prime} 53^{\prime \prime}$ west longitude at $650 \mathrm{~m}$ altitude. The climate of the region, according to the Köppen classification, is Cwb, mesothermic humid with rainy summers and dry winters. The mean air temperature and relative humidity, as well as accumulated precipitation were recorded during the period of conduction of the experiment (April to December 2016), and the values recorded were: $19.57^{\circ} \mathrm{C}$, UR $74.27 \%$ and precipitation of $526.6 \mathrm{~mm}$.

The experiment was carried out in randomized blocks, with four replications, arranged in a $5 \times 4$ (brown color fruit $x$ dry temperature) factorial scheme. There were five stages of maturation at harvest (plants with 20,40,60,80 and $100 \%$ brown fruits) and four drying temperatures (natural and artificial air at 30,45 and $60{ }^{\circ} \mathrm{C}$ ).

To produce the seeds, we used FMS Brilhante crambe seeds, from the Foundation MS. Soil tillage consisted of one plowing and two harrowing. Sowing was manual, in an area of $1.000 \mathrm{~m}^{2}$, using $0.50 \mathrm{~m}$ spacing between rows, with 20 seeds being sown per meter to a depth of $3 \mathrm{~cm}$, without the pre-definition of plots.

Planting fertilization and cover were based on the soil chemical characteristics, in the $0-20 \mathrm{~cm}$ depth layer, and carried out according to the recommendations for the crop (Pitol, 2008), which consisted of applying N:P:K formulation 4:14:8 (150 kg.ha ${ }^{-1}$ ) and, 25 days after planting, a cover fertilization with $45 \mathrm{~kg}$.ha ${ }^{-1}$ nitrogen, using urea as the source of $\mathrm{N}$. Technical recommendations were adopted for the best crop development, including irrigation in a conventional aspersion system and the control of weeds with manual weeding.

We performed manual harvesting according to the color of the fruits when the plants showed $20,40,60,80$ and $100 \%$ of brown fruits (total number of fruits of plant in such conditions). During the flowering phase, the plants were daily labeled and sampled until the percentage of brown fruits needed to harvest. Harvests corresponded to $38,45,52$, 59 and 67 days after the anthesis, respectively.

At the time of harvest, the plants were cut and taken to the laboratory, where the racemes were cut. The seeds were manually extracted and treated for the removal of barks and impurities. Then, the water content of the seeds was determined by the standard oven method at $105 \pm 3{ }^{\circ} \mathrm{C}$ for 24 hours (Brasil, 2009).

Subsequently, seed samples were submitted to drying with natural air (ambient with natural air circulation) and artificial drying (in a forced circulation oven, with drying air at 30,45 and $60{ }^{\circ} \mathrm{C}$ ) until reaching $10 \%$ of water content. Water loss by the seeds was monitored by periodic weighing until reaching the desired humidity degree.

After drying, the seeds were packed in closed paper bags and they were stored in an air-conditioned room with an average temperature of $20^{\circ} \mathrm{C}$ and relative humidity close to $55 \%$ until the humidity stabilized. Soon after the humidity stabilization, the seeds were weighed for yield determination. Data were corrected to $10 \%$ humidity adapting the equation proposed by Santos et al. (2005). After these procedures, the seeds were submitted to the following tests and/or determinations:

Seed oil content: the determination of the oil content occurred by the method of Nuclear Magnetic Resonance (Oxford, 1989); the apparatus was previously calibrated with trans esterified crambe oil, using three subsamples of 10 g seeds per replicate, with results expressed in percentages.

Germination test: conducted in plastic boxes, with three subsamples of 50 seeds per replicate. The seeds were distributed between two sheets of blotting paper, previously moistened with $\mathrm{KNO}_{3}$ solution in a volume equivalent to 2.5 times the weight of the dry paper. The boxes containing the seeds were placed in a B.O.D. germination chamber, regulated at a constant temperature of $25{ }^{\circ} \mathrm{C}$. We performed the evaluations on the fourth and seventh day after 
sowing, counting the number of normal seedlings, with the results expressed as a percentage, according to the criteria established by the RAS (Brasil, 2009).

First germination counting: conducted along with the germination test; it consisted of the number of normal seedlings on the fourth day after sowing (Brasil, 2009). The results are as percentage of normal seedlings.

Seedling emergence: conducted under uncontrolled greenhouse conditions, with sand substrate washed and sterilized in an oven at $200{ }^{\circ} \mathrm{C}$ for two hours. The seeds were sown $3 \mathrm{~cm}$ deep in plastic trays and the substrate was moistened with water equivalent to $60 \%$ of the retention capacity, keeping it in this condition with daily light irrigations (Brasil, 2009). We counted the number of normal seedlings from the seventh day after sowing, adopting as an evaluation criterion the seedlings that presented essential structures (root system, shoots with the first for leaves) developed and complete, with results expressed as percentage of emergence of seedlings.

The data were not transformed because they met the assumptions of the normality and homogeneity tests, being subjected to analysis of variance. The effects of the maturation stages were studied through regression analysis by choosing the appropriate models to represent them based on their biological behavior, the significance of the coefficients of the model and the coefficient of determination $\left(R^{2}\right)$. We used the Tukey test, at $5 \%$ probability, to study the effects of the drying temperatures.

\section{RESULTS AND DISCUSSION}

The average values of the weight of a thousand seeds indicated that the seeds from the first harvest had an estimated weight of $6.27 \mathrm{~g}$. From this maturation stage, the values increased until reaching the maximum weight of one thousand seeds $(7.38 \mathrm{~g})$, with an estimated harvest of $72.62 \%$ of brown color fruits (Figure 1 ). There was an increase of $17.70 \%$ in the weight of one thousand seeds of the first harvest until the maximum point. From this stage, there was a decrease of a small magnitude until the last harvest, when the seeds had an estimated value of $7.08 \mathrm{~g}$. These results can be explained since the beginning of seed development is characterized by the relatively slow accumulation of dry material, also affecting seed weight. After this step, the flow of dry matter accumulation is intensified to its maximum. From this point accumulated reserves begin to be degraded and this effect also impacts on the reduction of seed weight.

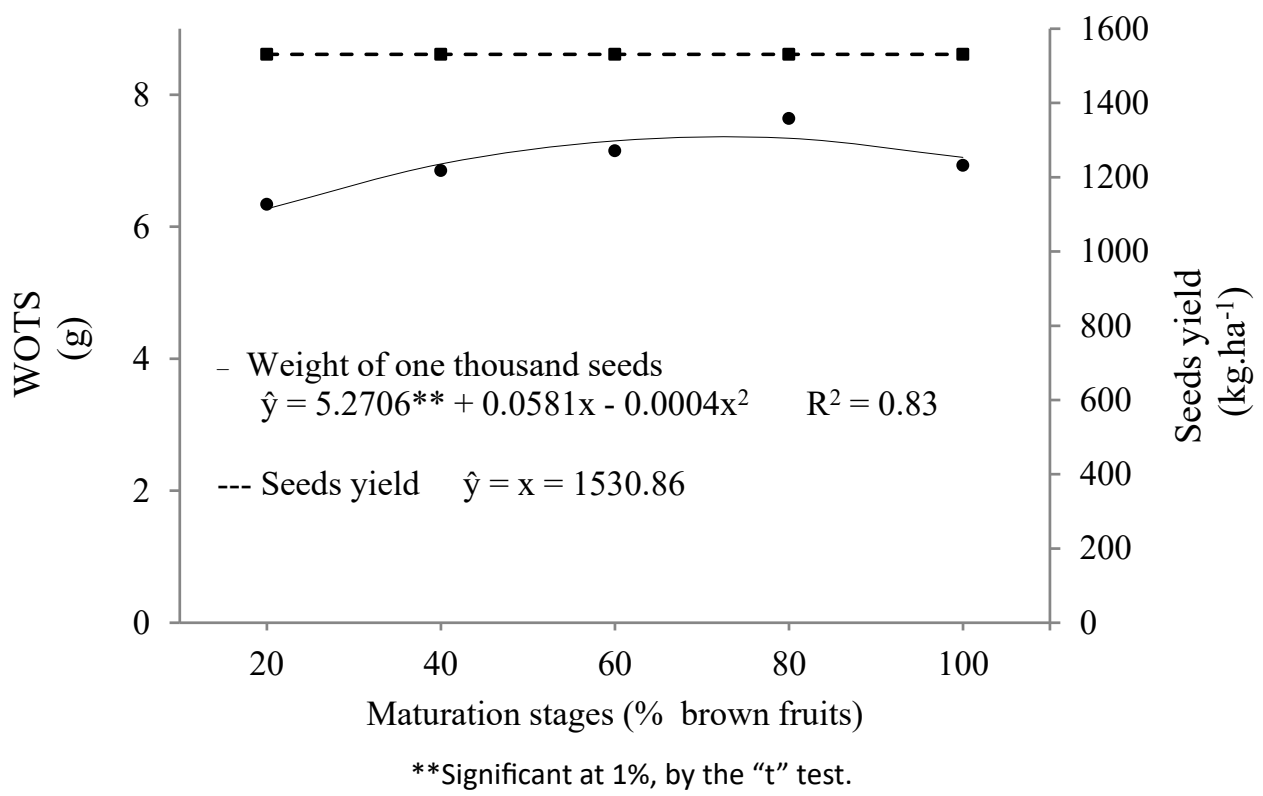

Figure 1. Weight of one thousand seeds - WOTS $(\mathrm{g})$ and seed yield $\left(\mathrm{kg}^{\mathrm{h}} \mathrm{ha}^{-1}\right)$ of crambe harvested at different maturation stages. 
Seed yield was not influenced by maturation stages (Figure 1), with average values of $1530.86 \mathrm{~kg}^{-h^{-1}}$. The productivity results are in accordance with those achieved by the MS Foundation, which proves that, when cultivated in soils of good to high fertility, crambe productivity varies from 1000 to $1500 \mathrm{~kg}^{-h a^{-1}}$ (Pitol, 2008).

The analysis of variance of the data revealed a significant effect of maturation stages (E) on all evaluated characteristics. Drying temperatures (S) significantly influenced germination, first germination counting and seedling emergence. Except for the oil content, the interaction $\mathrm{E} \times \mathrm{S}$ showed an effect on the other evaluated characteristics.

When the plants were with $20 \%$ brown fruits, harvesting showed seeds with $28.84 \%$ oil content (Figure 2 ). As the maturation stages prolonged, an increase in the oil content of the seeds occurred, reaching the maximum (35.92\%) when the plants showed $79.47 \%$ brown fruits. From this maturation stage, values reduced with average oil contents in the seeds close to $35.00 \%$ when the plants showed $100 \%$ brown fruits.

The determination of seed oil content as a function of fruit ripening stage and harvest time has also been studied by other authors. In a study with Jatropha fruits, Pessoa et al. (2012) found that to obtain oil the fruits can be harvested at any development stage when still adhered to the plant. However, the authors reported that the highest levels are found from stage II, characterized by yellow fruits with shiny black seeds. Ducca et al. (2015) concluded that harvesting Jatropha seeds should occur from 75 days after flowering to maximize oil yield, dry matter mass and physiological quality of seeds.

The different drying temperatures did not influence the oil content of crambe seeds (Figure 3), with values close to $33.00 \%$. Silva et al. (2013), when evaluating the drying effect with warm air, with natural air, in the farmyard, in the shade and drying in the field on the quality of crude oil of crambe grains, concluded that the different methods did not interfere in the quality of crude oil. Harris et al. (1978) report that high temperatures during seed development are associated with the reduction in total oil content. Under field conditions, this effect is variable according to other environmental factors such as water stress, thus affecting oil production by the effects on seed growth and development.

The germination results of seeds harvested at different fruit ripening stages and submitted to drying revealed that the values of natural air drying and $30{ }^{\circ} \mathrm{C}$ were adjusted to the quadratic behavior models, while the temperatures of 45 and $60{ }^{\circ} \mathrm{C}$ showed a cubic effect obtained values (Figure 4). For natural air-drying, germination was initially at $21 \%$, with results increasing until $75.31 \%$ of brown fruits at the time of germination (69\%). At this development stage, even though the water content is high (29.48\%), the seeds have already acquired germination potential, mainly due to the accumulation of reserves. From this maturation stage, there was a reduction in values. In the last harvest, the germination was at $59 \%$.

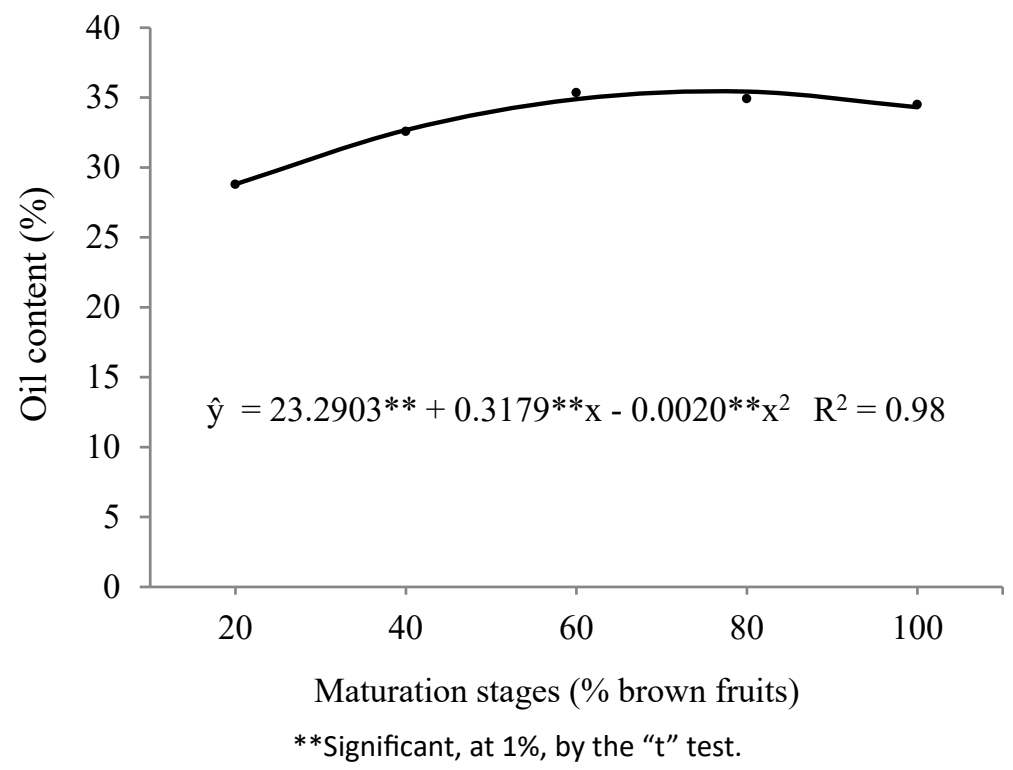

Figure 2. Seed oil content (\%) of crambe harvested at different maturation stages. 


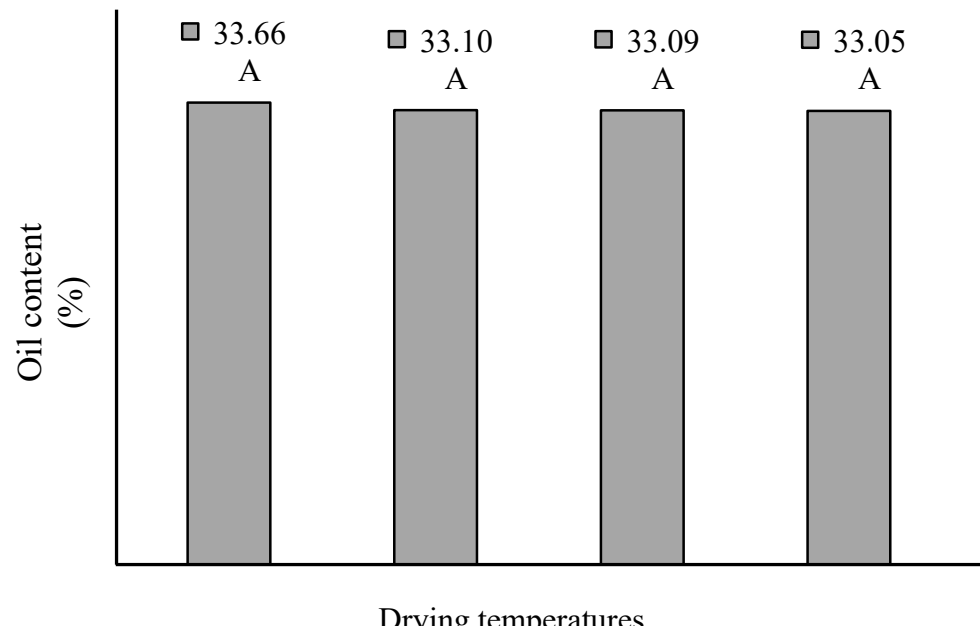

Means followed by different letters in the columns differ among themselves at $5 \%$ probability, by the Tukey test.

Figure 3. Seed oil content (\%) of crambe submitted to different drying temperatures.

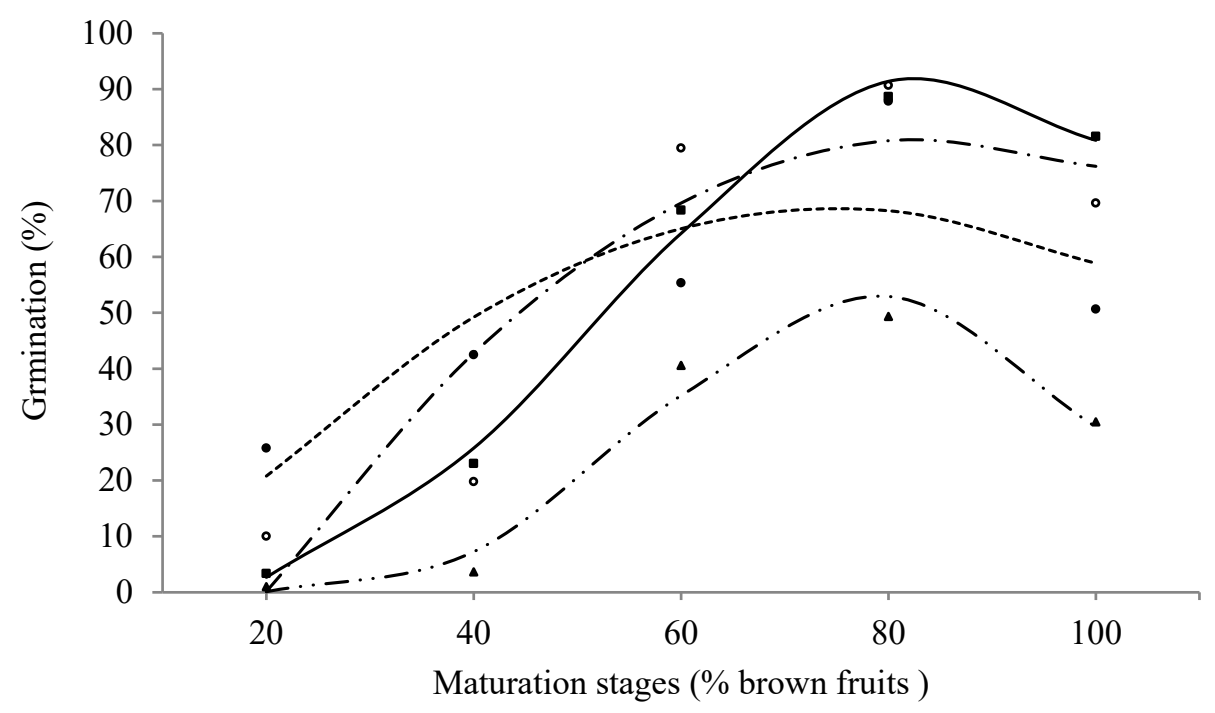

\begin{tabular}{|c|c|c|}
\hline $\begin{array}{c}\text { Drying } \\
\text { Temperatures }\end{array}$ & Regression Equation & $\mathrm{R}^{2}$ \\
\hline - Natural air & $\ldots \hat{\mathrm{y}}=-20.1960 * *+2.3649 * * \mathrm{x}-0.0157 * * \mathrm{x}^{2}$ & 0.70 \\
\hline$\circ 30^{\circ} \mathrm{C}$ & $-\cdot-\hat{\mathrm{y}}=-58.1965 * *+3.3104 * * \mathrm{x}-0.0196 * * \mathrm{x}^{2}$ & 0.83 \\
\hline $.45^{\circ} \mathrm{C}$ & $-\hat{y}=21.4095-2.425491 * x+0.085482 * * x^{2}-0.000553 * * x^{3}$ & 0.99 \\
\hline$\Delta 60^{\circ} \mathrm{C}$ & $-\cdots-\hat{y}=44.602 * *-4.032039 * * x+0.103229 * * x^{2}-0.000644 * * x^{3}$ & 0.97 \\
\hline
\end{tabular}

Figure 4. Seed germination (\%) of crambe harvested at different maturation stages and submitted to different drying temperatures.

In a study with crambe seeds, Oliveira et al. (2014) verified germination higher than $70 \%$ in the first harvest season at 14 days after flowering. However, germination reduced significantly until the last harvest, with values close to $44 \%$. In this study, the low germination percentage observed in the early stages of maturation may be associated with the indeterminate flowering habit of the crambe crop and the post-harvest dormancy of its seeds. According to Costa et al. 
(2011), the unevenness present in the crambe racemes possibly contributed to seed dormancy in different degrees. In addition to genetic factors, some environmental factors, such as day length, light quality, mineral nutrition, competition, temperature, physiological stage of the plant and the position of the seed in the parent plant have a great influence on dormancy during its development (Hilhorst, 2007).

The maximum germination percentage (82\%), when the seeds were submitted to drying air at $30{ }^{\circ} \mathrm{C}$, occurred in the stage with $84.44 \%$ of brown fruits, occurring, from this stage, a reduction in values (Figure 4 ). In the first harvesting season, there was practically no germination when the seeds were exposed at temperatures of 30,45 and $60^{\circ} \mathrm{C}$. This result can be explained since the seeds were still in the development process, presenting high water content. Thus, drying at these temperatures may have caused damage to the embryo, because at this development stage the seeds do not yet present the desiccation tolerance mechanisms sufficiently active to respond efficiently to the stresses, as reported by Bewley et al. (2013).

In addition, Bewley et al. (2013) reported that premature desiccation affects synthesis of proteins as well as synthesis of enzymes essential for the development and germination of seeds. Therefore, removal of the seeds from the plant, with subsequent rapid drying, can determine the complete feasibility loss, depending on the stage of development in which it occurs and the species. The seed cell membranes system remains disorganized during most of the transfer period of plant matter for the seeds (Abdul-Baki and Anderson, 1972). It is further verified that at $45^{\circ} \mathrm{C}$ the maximum germination percentage was $91 \%$ while seeds submitted at $60^{\circ} \mathrm{C}$ showed the maximum germination estimated at $53 \%$ (Figure 4).

It appears that, regardless of the harvesting season, the seeds exposed to the drying temperature of $60{ }^{\circ} \mathrm{C}$ (Figure 4) showed germination below the standard established for the commercialization of seeds of oil species of the same crambe family, such as canola, which is $70 \%$ germination for basic seeds (Brasil, 2013).

Analyzing the effects of drying temperatures within each stage of maturation, the use of temperature at $60^{\circ} \mathrm{C}$ was detrimental to the germination of the seeds harvested at all stages of maturation (Table 1). The lower germination percentage of seeds from all fruit ripening stages at $60{ }^{\circ} \mathrm{C}$ is possibly associated with deterioration of seed cell membranes, as already reported.

In other studies, with crambe seeds, Faria et al. (2014) reported that the temperature between 40 and $60{ }^{\circ} \mathrm{C}$ provided better physiological performance of crambe seeds while the at $70{ }^{\circ} \mathrm{C}$ it was detrimental. Regarding the drying methods, Oliva et al. (2012) observed that there was no immediate negative effect of shade drying, drying with unheated air, drying with heated air, drying in the farmyard and drying in the field on the quality of crambe seeds. The drying method in the plant provided lower number of dead seeds in relation to the other treatments.

In post-harvest seeds of Jatropha, drying is the most used process to ensure its quality (Ullmann et al., 2010). The authors verified that the drying temperature of the seeds affects their physiological quality. As the drying temperature increases, mechanical damage of the Jatropha seeds occurs; however, germination is still high. Evaluating Jatropha seeds, Zonta et al. (2011) reported that the seeds can be dried in the sun at temperatures of 33 and $43^{\circ} \mathrm{C}$. They also

Table 1. Seed germination (\%) of crambe harvested at different maturation stages and submitted to different drying temperatures.

\begin{tabular}{ccccccc}
\hline \multirow{2}{*}{ Drying Temperatures } & \multicolumn{4}{c}{ Maturation Stages (\% brown fruits) } & \multicolumn{3}{c}{ Means } \\
\cline { 2 - 7 } & 20 & 40 & 60 & 80 & 100 & 52.42 \\
\hline Natural air & $25.77 \mathrm{~A}$ & $42.49 \mathrm{~A}$ & $55.35 \mathrm{C}$ & $87.83 \mathrm{~A}$ & $50.66 \mathrm{C}$ & 53.90 \\
$30{ }^{\circ} \mathrm{C}$ & $10.00 \mathrm{~B}$ & $19.77 \mathrm{~B}$ & $79.47 \mathrm{~A}$ & $90.66 \mathrm{~A}$ & $69.63 \mathrm{~B}$ & 52.98 \\
$45^{\circ} \mathrm{C}$ & $3.35 \mathrm{C}$ & $23.03 \mathrm{~B}$ & $68.33 \mathrm{~B}$ & $88.66 \mathrm{~A}$ & $81.55 \mathrm{~A}$ & 25.01 \\
$60{ }^{\circ} \mathrm{C}$ & $1.00 \mathrm{C}$ & $3.66 \mathrm{C}$ & $40.58 \mathrm{D}$ & $49.33 \mathrm{~B}$ & $30.49 \mathrm{D}$ & 58.08 \\
\hline Means & 10.03 & 22.23 & 60.93 & 78.97 & 58 &
\end{tabular}

Means followed by different letters in the column differ from each other at $5 \%$ probability, by the Tukey test. 
found that at $43^{\circ} \mathrm{C}$ there is less drying time, better germination, and vigor of Jatropha seeds. According to the authors, shade drying is detrimental to seed quality.

Figure 5 shows the values for the first seed germination test, harvested at different maturation stages, and submitted to drying methods. The results from drying with natural air and at $60^{\circ} \mathrm{C}$ adjusted to quadratic behavior models while temperatures at 30 and $45{ }^{\circ} \mathrm{C}$ showed a cubic effect in the obtained values.

For seed drying with natural air, the germination was $6 \%$ when the plants had $20 \%$ brown fruits. There were increases in the percentage of normal seedlings up to the stage with $82.04 \%$ brown fruits when it reached its maximum vigor value (61\%). From this maturation stage, the values reduced, observing that harvests with $100 \%$ brown fruits resulted in $56 \%$ germination at the first test counting (Figure 5 ).

Seeds submitted to $60^{\circ} \mathrm{C}$ also showed values of the first germination counting, adjusting to a quadratic model. This temperature was detrimental to seed quality regardless of maturation stages since the maximum value was $31 \%$ germination at the first counting, for a harvest with $79.86 \%$ brown fruits (Figure 5). Better results occurred when the seeds were dried at 30 and $45^{\circ} \mathrm{C}$, presenting, respectively, 83 and $89 \%$ of maximum germination in the first count (Figure 5).

The development of the $\mathrm{E} \times \mathrm{S}$ interaction, studying the effect of drying temperatures within each stage of maturation, revealed that seed exposure to drying air at $60^{\circ} \mathrm{C}$ was detrimental to seed quality from different stages of maturation (Table 2). The data from the first count followed the trend of those observed in seed germination, indicating that drying with natural air and with mild temperatures $\left(30\right.$ and $45^{\circ} \mathrm{C}$ ) enhanced the production of more vigorous seeds especially when they were harvested from plants with $80 \%$ of brown fruits. At this stage of maturation, the values obtained were higher than $80 \%$ of germination even at the first count of the test. Drying at $60{ }^{\circ} \mathrm{C}$ was also detrimental to seed vigor in

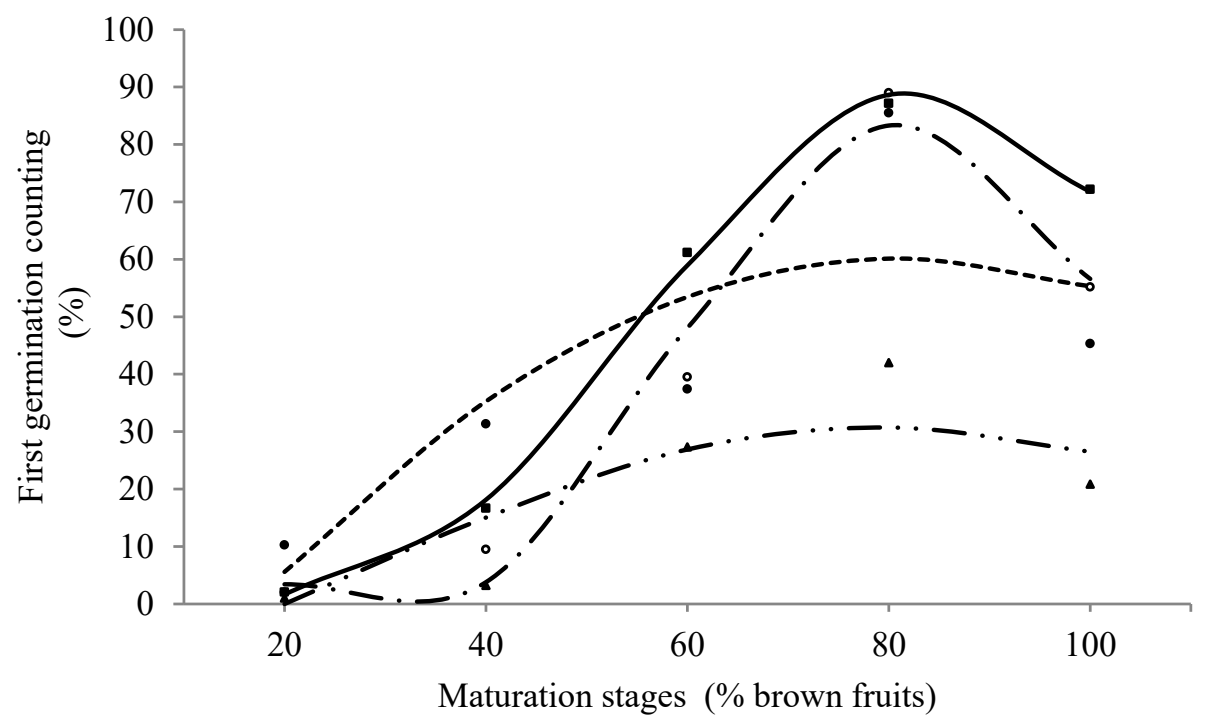

\begin{tabular}{|c|c|c|}
\hline $\begin{array}{c}\text { Drying } \\
\text { Temperatures }\end{array}$ & Regression Equation & $\mathrm{R}^{2}$ \\
\hline - Natural air & $\ldots \hat{\mathrm{y}}=-35.5795^{* *}+2.3464 * * \mathrm{x}-0.0143^{* *} \mathrm{x}^{2}$ & 0.65 \\
\hline$\circ 30^{\circ} \mathrm{C}$ & $-\cdot-\hat{y}=99.86 * *-8.123783 * * x+0.18715^{* *} x^{2}-0.001102 * * x^{3}$ & 0.97 \\
\hline - $45^{\circ} \mathrm{C}$ & $-\hat{y}=44.9115^{*}-4.24686^{* *} x+0.118964 * * x^{2}-0.000738 * * x^{3}$ & 0.99 \\
\hline$\Delta 60^{\circ} \mathrm{C}$ & $-\cdots-\hat{\mathrm{y}}=-32.7645^{* *}+1.5973 * * \mathrm{x}-0.0100 * * \mathrm{x}^{2}$ & 0.71 \\
\hline
\end{tabular}

Figure 5. First seed germination counting (\%) of crambe harvested at different maturation stages and submitted to different drying temperatures. 
most fruit ripening stages (Table 2).

For all drying temperatures, there was a cubic effect on the emergence of seedlings (Figure 6). The ripening stage with $40 \%$ brown fruits presented the lowest results. From this stage there was an increase in the values obtained, and seeds from the stage with $80 \%$ brown fruits presented the best results of seedling emergence. Seeds dried in natural air showed $51 \%$ of seedlings emerged, while air drying at 30,45 and $60{ }^{\circ} \mathrm{C}$ the values found were 55,53 and $48 \%$ of seedling emergence, respectively. The later harvest, with $100 \%$ brown fruits, was detrimental to seed vigor, regardless of the drying temperature.

In the research work, the data are contradictory regarding the moment when the maximum germination occurs in

Table 2. First seed germination counting (\%) of crambe harvested at different maturation stages and submitted to different drying temperatures.

\begin{tabular}{ccccccc}
\hline \multirow{2}{*}{ Drying Temperatures } & \multicolumn{9}{c}{ Maturation Stages (\% brown fruits) } & \multicolumn{1}{c}{ Means } \\
\cline { 2 - 7 } & 20 & 40 & 60 & 80 & 100 & 42.00 \\
\hline Natural air & $10.50 \mathrm{~A}$ & $31.30 \mathrm{~A}$ & $37.40 \mathrm{~B}$ & $85.50 \mathrm{~A}$ & $45.30 \mathrm{~B}$ & 38.98 \\
$30{ }^{\circ} \mathrm{C}$ & $2.00 \mathrm{~B}$ & $9.40 \mathrm{~B}$ & $39.50 \mathrm{~B}$ & $88.90 \mathrm{~A}$ & $55.10 \mathrm{~B}$ & 38.78 \\
$45^{\circ} \mathrm{C}$ & $2.00 \mathrm{~B}$ & $16.60 \mathrm{~B}$ & $61.10 \mathrm{~A}$ & $87.10 \mathrm{~A}$ & $72.10 \mathrm{~A}$ & 18.86 \\
$60^{\circ} \mathrm{C}$ & $1.00 \mathrm{~B}$ & $3.20 \mathrm{C}$ & $27.30 \mathrm{C}$ & $42.00 \mathrm{~B}$ & $20.80 \mathrm{C}$ & 47.80 \\
\hline Means & 3.87 & 15.12 & 41.32 & 75.87 & &
\end{tabular}

Means followed by different letters in the column differ from each other at $5 \%$ probability, by the Tukey test.

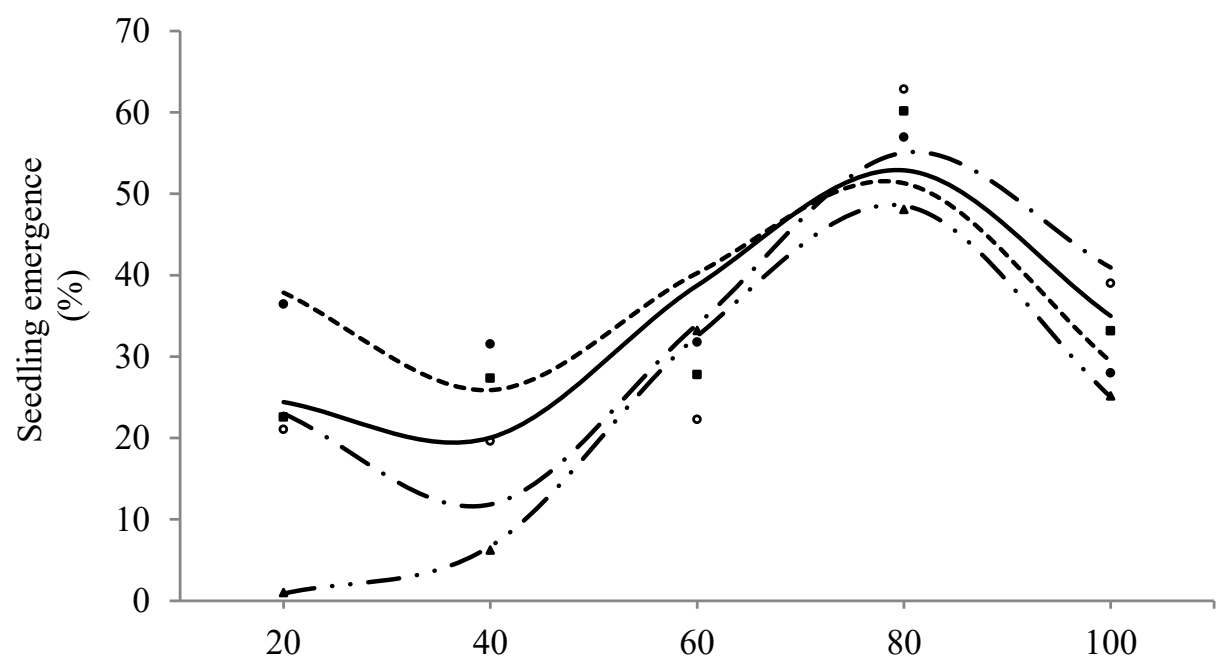

Maturation stages ( $\%$ brown fruits)

\begin{tabular}{lll}
\hline $\begin{array}{c}\text { Drying } \\
\text { Temperatures }\end{array}$ & \multicolumn{1}{c}{ Regression Equation } & $\mathrm{R}^{2}$ \\
\hline- Natural air & $\cdots . \hat{\mathrm{y}}=105.8205^{* *}-5.291315^{* *} \mathrm{x}+0.107032^{* *} \mathrm{x}^{2}-0.000618^{* *} \mathrm{x}^{3}$ & 0.74 \\
\hline$\circ 30^{\circ} \mathrm{C}$ & $-\cdot-\hat{\mathrm{y}}=101.618^{* *}-6.189723^{* *} \mathrm{x}+0.127165^{* *} \mathrm{x}^{2}-0.000713^{*} \mathrm{x}^{3}$ & 0.80 \\
\hline$-45^{\circ} \mathrm{C}$ & $-\hat{\mathrm{y}}=79.3390-4.470381^{* *} \mathrm{x}+0.097649 * * \mathrm{x}^{2}-0.000574 * * \mathrm{x}^{3}$ & 0.74 \\
\hline $\mathbf{\Delta} 60^{\circ} \mathrm{C}$ & $-\cdots-\hat{\mathrm{y}}=44.7855^{*}-3.933991^{*} \mathrm{x}+0.099343^{*} \mathrm{x}^{2}-0.00062^{* *} \mathrm{x}^{3}$ & 0.99 \\
\hline & $* *$ and $*$ significant at 1 and $5 \%$ by the $" \mathrm{t}$ " test, respectively.
\end{tabular}

Figure 6. Seedling emergence (\%) of crambe from seeds harvested at different maturation stages and submitted to different drying temperatures. 
Table 3. Seedling emergence (\%) of crambe from seeds harvested at different maturation stages and submitted to different drying temperatures.

\begin{tabular}{ccccccc}
\hline \multirow{2}{*}{ Drying Temperatures } & \multicolumn{9}{c}{ Maturation Stages (\% brown fruits) } & \multicolumn{3}{c}{ Means } \\
\cline { 2 - 7 } & 20 & 40 & 60 & 80 & 100 & 36.94 \\
\hline Natural air & $36.45 \mathrm{~A}$ & $31.53 \mathrm{~A}$ & $31.78 \mathrm{~A}$ & $56.95 \mathrm{~A}$ & $27.99 \mathrm{~B}$ & 32.95 \\
$30^{\circ} \mathrm{C}$ & $21.04 \mathrm{~B}$ & $19.61 \mathrm{~B}$ & $22.28 \mathrm{~B}$ & $62.83 \mathrm{~A}$ & $38.99 \mathrm{~A}$ & 34.19 \\
$45^{\circ} \mathrm{C}$ & $22.57 \mathrm{~B}$ & $27.33 \mathrm{~A}$ & $27.77 \mathrm{~A}$ & $60.16 \mathrm{~A}$ & $33.16 \mathrm{~A}$ & 22.90 \\
$60^{\circ} \mathrm{C}$ & $1.00 \mathrm{C}$ & $6.24 \mathrm{C}$ & $33.20 \mathrm{~A}$ & $48.07 \mathrm{~B}$ & $25.99 \mathrm{~B}$ & 31.53 \\
\hline Means & 20.26 & 21.17 & 28.75 & 57.00 & 3 & \\
\hline
\end{tabular}

Means followed by different letters in the column differ from each other at $5 \%$ probability, by the Tukey test.

relation to the maximum accumulation of dry matter. According to Marcos-Filho (2015), the physiological maturity point of seeds is marked by the maximum accumulation of dry matter mass, by the maximum physiological quality, besides water loss. Ellis and Pietra Filho (1992), working with different species, suggested that the maximum physiological potential would only occur after the seed physiological maturity. These authors proposed the term "mass maturity" to characterize the time of occurrence of the maximum mass of dry matter, considering that this moment does not coincide with maximum vigor and germination.

In this work, the maximum germination and vigor points, by first counting and seedling emergence tests, occurred after the maximum accumulation of dry matter, which was estimated when the plants showed $67.81 \%$ brown fruits, therefore, before the stage of maximum germination, according to the information of Ellis and Pietra Filho (1992).

The results of drying temperatures within each maturation stage also revealed a detrimental effect of $60{ }^{\circ} \mathrm{C}$ on seedling emergence (Table 3). The post-harvest drying occurs to reduce the humidity content of the seeds to safe levels, aiming to attenuate the possibility of injuries during handling and to allow the proper preservation of the physiological performance during storage. However, it is necessary that artificial drying be conducted with due care and speed sufficient to remove water capable of accelerating the destructive metabolism without promoting seed disturbance, usually caused by the use of elevated temperatures and mechanical damage during drying (Marcos-Filho, 2015).

\section{CONCLUSIONS}

Crambe seeds, FMS Brilhante cultivar, reach the maximum oil content with harvests made from $70 \%$ of total brown fruits.

Drying temperatures do not affect the oil content of the seeds.

Harvesting crambe seed aiming at the highest physiological quality should occur when the plants have between 75 and $85 \%$ brown fruits.

Artificial drying at 30 and $45^{\circ} \mathrm{C}$ can be recommended for crambe seeds, favoring the production of quality seeds.

\section{ACKNOWLEDGEMENTS}

To the Conselho Nacional de Desenvolvimento Cientifico e Tecnológico (CNPq), the Coordenação de Aperfeiçoamento de Pessoal de Nível Superior (CAPES), and the Fundação de Amparo à Pesquisa do Estado de Minas Gerais (FAPEMIG), for granting scholarships and financial support. 


\section{REFERENCES}

ABDUL-BAKI, A.A.; ANDERSON, J.D. Physiological and biochemical deterioration of seeds. In: KOZLOWSKI, T.T. (Ed.). Seed Biological. New York: Academic Press, 1972. p.283-315.

BEWLEY, J.D.; BRADFORD, K.J.; HILHORST, H.W.M.; NONOGAKI, H. Seeds: physiology of development, germination and dormancy. 3. ed. New York: Springer, 2013. 392p.

BRASIL. Ministério da Agricultura, Pecuária e Abastecimento. Instrução Normativa 45/2013. Anexo VII - Padrões para a produção e a comercialização de sementes de canola. Brasília, DF. [Diário Oficial da República Federativa do Brasil], 2013. p.5. https://www.gov. br/agricultura/pt-br/assuntos/insumos-agropecuarios/insumos-agricolas/sementes-e-mudas/publicacoes-sementes-e-mudas/ copy_of_INN45de17desetembrode2013.pdf

BRASIL. Ministério da Agricultura, Pecuária e Abastecimento. Regras para análise de sementes. Ministério da Agricultura, Pecuária e Abastecimento. Secretaria de Defesa Agropecuária. Brasília: MAPA/ACS, 2009. 395p. http:// www.agricultura.gov.br/arq_editor/ file/2946_regras_analise_sementes.pdf

CARVALHO, N.M.; NAKAGAWA, J. Sementes: ciência, tecnologia e produção. 5. ed. Jaboticabal: FUNEP, 2012. 590p.

COLODETTI, T.V.; MARTINS, L.D.; RODRIGUES, W.N.; BRINATE, S.V.B.; TOMAZ, M.A. Crambe: aspectos gerais da produção agrícola. Enciclopédia Biosfera, Centro Científico Conhecer, v.8, p.258-269, 2012. http://www.conhecer.org.br/enciclop/2012a/agrarias/ crambe.pdf

COSTA, L.M.; RESENDE, O.; GONÇALVES, D.N.; SOUSA, K.A. Coeficiente de difusão efetivo para a secagem de sementes de crambe (Crambe abyssinica). Revista Brasileira de Engenharia Agrícola e Ambiental, v.15, n.10, p.1089-1096, 2011. https://doi.org/10.1590/ S1415-43662011001000014

COSTA, L.M.; RESENDE, O.; GONÇALVES, D.N.; SOUZA, K.A.; SALES, J.F.; DONADON, J.R. The influence of drying on the physiological quality of crambe fruits. Acta Scientiarum - Agronomy, v.34, n.2, p.213-218, 2012. https://doi.org/10.4025/actasciagron. v34i2.12482

COSTA, L.M.; RESENDE, O.; OLIVEIRA, D.E.C. Isotermas de dessorção e calor isostérico dos frutos de crambe. Revista Brasileira Engenharia Agrícola e Ambiental, v.17, n.4, p.412-418, 2013. https://doi.org/10.1590/S1415-43662013000400009

DUCCA, C.A.D.; SOUZA, N.M.; PRETE, C.E.C. Qualidade fisiológica e lipídios totais de sementes de pinhão-manso (Jatropha curcas L.) em função de épocas de colheita. Revista Brasileira de Engenharia Agrícola e Ambiental, v.19, n.4, p.364-368, 2015. https://doi. org/10.1590/1807-1929/agriambi.v19n4p364-368.

ELLIS, R.H.; PIETRA-FILHO, C. Seed development and cereal seed longevity. Seed Science Research, v.2, p.9-15, 1992.

FARIA, R.Q.; TEIXEIRA, I.R.; CUNHA, D.A.; HONORATO, J.M.; DEVILLA, I.A. Qualidade fisiológica de sementes de crambe submetidas à secagem. Revista Ciência Agronômica, v.45, n.3, p.453-460, 2014. http://ccarevista.ufc.br/seer/index.php/ccarevista/article/ view/2306

FARIA, R.Q.; TEIXEIRA, I.R.; DEVILLA, I.A.; ASCHERI, D.P.R.; RESENDE, O. Cinética de secagem de sementes de crambe. Revista Brasileira de Engenharia Agrícola e Ambiental, v.16, n.5, p.573-583, 2012. https://doi.org/10.1590/S1415-43662012000500014

GARCIA, D.C.; BARROS, A.C.S.A.; PESKE, S.T.; MENEZES, N.L. A secagem de sementes. Ciência Rural, v.34, n.2, p.603-608, 2004. https://doi.org/10.1590/S0103-84782004000200045

HARRIS, H.C.; McWILLIAM, J.R.; MASON, W.K. Influence of temperature on oil content and composition of sunflower feed. Australian Journal of Agricultural Research, v.29, n.3, p.1203-1212, 1978.

HILHORST, H.W.M. Definitions and hypotheses of seed dormancy. In: BRADFORD, K.J.; NONOGAKI, H. Seed development, dormancy and germination. Oxford: Blackwell, 2007. p.50-71.

LUCENA, A.M.A.; CAVALCANTI, N.T.F.; FARIAS, A.L.; SANTOS, K.S.; ARRIEL, N.H.C.; ALBUQUERQUE, F.A. Qualidade de sementes de gergelim colhidas de frutos em diferentes estádios de maturação. Scientia Plena, v.9, n.6, p.1-7, 2013. https://www.scientiaplena. org.br/sp/article/view/1358 
LUCENA, A.M.A.; SEVERINO, L.S.; FREIRE, M.A.O.; COSTA, F.X.; BELTRÃO, N.E.M. Umidade e peso seco da semente e do fruto de mamona BRS Paraguaçu colhidos em três estádios de maturação. In: CONGRESSO BRASILEIRO DE MAMONA, 2., 2006, Campina Grande. Anais... Campina Grande: Embrapa Algodão, 2006. CD-ROM.

MARCOS-FILHO, J. Fisiologia de sementes de plantas cultivadas. 2. ed. Londrina: ABRATES, 2015. 660p.

MARTINS, L.D.; COSTA, F.P.; LOPES, J.C.; RODRIGUES, W.N. Influence of pre-germination treatments and temperature on the germination of crambe seeds (Crambe abyssinica Hochst). Idesia, v.30, n.3, p.23-28, 2012. http://dx.doi.org/10.4067/S071834292012000300003

MELO, P.C.T.; RIBEIRO, A. Produção de sementes de cebola: cultivares de polinização aberta e híbridos. In: CASTELLANE, P.D.; NICOLOSI, W.M.; HASEGAWA, M. (Ed.). Produção de sementes de hortaliças. Jaboticabal: FCAV/FUNEP, 1990. p.15-59.

OLIVA, A.C.E.; BIAGGIONI, M.A.M.; CAVARIANI, C. Efeito imediato do método de secagem na qualidade de sementes de crambe. Revista Energia na Agricultura, v.27, n.3, p.16-30, 2012. https://doi.org/10.17224/EnergAgric.2012v27n3p16-30

OLIVEIRA, M.B.; DAVID, A.M.S.S.; AMARO, H.T.R.; ASSIS, M.O.; RODRIGUES, B.R.A.; ASPIAZÚ, I.; CARVALHO, A.J. Épocas de colheita e qualidade fisiológica de sementes de crambe. Semina: Ciências Agrárias, v.35, n.4, p.1785-1792, 2014. http://www.uel.br/revistas// uel/index.php/semagrarias/article/view/13750

OXFORD INSTRUMENTS ANALYTICAL SYSTEMS DIVISION - OXFORD 4000. Analyser multi point calibration. VT Magnet rapid solid liquid ratio oil in wet rape and sunflower seeds. Abingdon: Oxfordshire, n.p. (Supplement to Instruction Manual, NA - 23-IT). 1989.

PESSOA, A.M.S.; MANN, R.S.; SANTOS, A.S.; RIBEIRO, M.L.F. Influência da maturação de frutos na germinação, vigor e teor de óleo de sementes de pinhão-manso (Jatropha curcas L.). Scientia Plena, v.8, n.7, p.1-11, 2012. https://www.scientiaplena.org.br/sp/ article/view/407

PITOL, C. Cultura do crambe. Tecnologia e Produção: milho safrinha e culturas de inverno, 2008. p.85-88.

SANTOS, J.B.; FERREIRA, E.A.; SILVA, A.A.; SILVA, F.M.; SANTOS, E.A.; FERREIRA, L.R. Avaliação do carfentrazone-ethyl como dessecante em pré-colheita de sementes de feijão. Revista Ceres, v.52, n.304, p.831-843, 2005. http://www.ceres.ufv.br/ojs/index. php/ceres/article/view/3091

SILVA, M. A. P.; BIGGIONI, M. A. M.; SPEROTTO, F. C. S.; BEZERRA, P. H. S.; BRANDÃO, F. J. B. Qualidade do óleo bruto de grãos de crambe (Crambe abyssinica Hochst) sob diferentes métodos de secagem. Revista Energia na Agricultura, v. 28, n. 3, p. 193-199, 2013. https://doi.org/10.17224/EnergAgric.2013v28n3p193-198

SMANIOTTO, T.A.S.; RESENDE, O.; MARÇAL, K.A.F.; OLIVEIRA, D.E.C.; SIMON, G.A. Qualidade fisiológica das sementes de soja armazenadas em diferentes condições. Revista Brasileira de Engenharia Agrícola e Ambiental, v.18, n.4, p.446-453, 2014. http:// www.agriambi.com.br/revista/v18n04/v18n04a13.pdf

ULLMANN, R.; RESENDE, O.; SALES, J.F.; CHAVES, T.H. Qualidade das sementes de pinhão manso submetidas à secagem artificial. Revista Ciência Agronômica, v.41, n.3, p.442-447, 2010. http://www.scielo.br/scielo.php?script=sci_ arttext\&pid=S1806-66902010000300017

ZONTA, J.B.; ARAUJO, E.F.; ARAUJO, R.F.; DIAS, L.A.S. Diferentes tipos de secagem: efeitos na qualidade fisiológica de sementes de pinhão-manso. Revista Brasileira de Sementes, v.33, n.4, p.721-731, 2011. http://www.scielo.br/scielo.php?script=sci_ arttext\&pid=S0101-31222011000400014 